\title{
Investigating the relationship between credit risk indicators and timely fulfillment of the customers' obligations (a case study of bank sepah branches in east Azerbaijan and Ardabil regions)
}

\author{
Dariosh Azimi *, Younes Badavar Nahandi \\ Department of Accounting, Tabriz Branch, Islamic Azad University, Tabriz, IRAN \\ *Corresponding authorE-mail: acc.azimi@gmail.com
}

\begin{abstract}
This research was conducted with the aim to investigate and identify the relationship between credit risk indicators and timely fulfillment of the legal customers' obligations of Sepah Bank. To do this, credit data and financial ratios of 370 cases of Sepah's Bank legal customers who had used credit services of Sepah Bank branches in East Azerbaijan and Ardabil regions during a period from 2012-2014 were collected. In this respect, data related to 27 financial ratios as explanatory variables of 370 cases of the mentioned sample were extracted from their credit files and were selected to be tested after performing required refinement and classifying in two groups of extracted data from audited and unaudited financial statements. Then the relationships between these variables and timely fulfillment of obligations were investigated using logistic regression method and considering the significance of the independent variables at $95 \%$ confidence level. The results of the research showed that accounting, current, and acid test ratios, working capital, return on total assets, return on equity and gross profit to sell listed in unaudited financial statements group and current ratio/ liquidity ratio, current assets ratio, accounts receivable turnover ratio, return on total assets, debt-to-equity ratio, debt to asset ratio, current debts to equity ratio listed in audited financial statements group have a significant relationship with timely fulfillment of the customers' obligations.
\end{abstract}

Keywords: Sepah Bank; Obligations; Credit Risk; Logistic Regression.

\section{Introduction}

In today's world, the unique role of banks in the country's economic cycle in helping country develop and grow by absorbing small and big wandering resources and directing them toward productive sectors is unknown to no one. As the most important economic institutions of the society and the most genuine alternative of money market in economy, banks are responsible to manage and provide liquidity and direct and channel it towards productive activities and investments such that the most important liquidity of the society economy should be directed and managed by country's banking system to invest in different economic sectors. But what is obvious is that today banking as a supplement for money and currency is one of the most important components that provides infrastructure of country's development in economic dimensions. That is, by virtue of economic principles, no progress will be achieved unless more savings are made, and they are used more effectively toward development. As the most important economic institutes of the society, banks have a solemn duty to attract, absorb and redirect the funds of depositors. By redirecting resources toward production and service sectors, banking system paves the way for growth and economic development while makes production, creates jobs and fulfills its social responsibilities. This way, banks gather surplus deposits available to the public and by awarding loans to those in need does their traditional duty that is, mediate between depositors and borrowers (Erfani \& Hemati 2014).

Though banks present a variety of services, equipping resources in the form of deposits and along with it, optimal allocation of resources in the form of granted facilities has retained their pivotal role in the field of banking activities.

Meanwhile, banks as a depositary lawyer invest people's outstanding deposits into profitable projects and provide the expected returns by themselves and people. Though banks try to get commissions from services (commission-oriented), the interest on facilities granted is considered to be the main component of bank revenue. Using their credit operations, banks create conditions to transfer resources from persons who are not willing or able to participate directly in economic activities to those who need capital for performing economic affairs, and therefore, play their economic mediating role and cause an increase in the country productions. By increasing production, the employment level in the society improves and on the other hand, by increasing goods and services in a balanced economy, the conditions to reduce prices are provided (Bahmand \& Bahmani 2007).

This way, the importance of granting credit facility is determined in the perspective of the facility's receiver, banks (bank that grants facility), depositors and finally the entire economy of the society. The investigation of granting credit facility is a theoretical issue and is not conducted in the form of a special formula, and this feature makes the definitive confirmation or rejection difficult in 
credit decision makings. Especially, this problem becomes more acute when granting facilities are linked to economic, social, political and cultural issues. Similar to other techniques, in credit decision makings, basic criteria and fundamental standards are presented by experts and professional communities and gradually recognized to be acceptable; these criteria are the result of human's personal and theoretical judgment and can be changed, justified and corrected. The use of these criteria and standards guarantees the health and strength of credit basis that is, the realization of the principle "ensuring the return of the original allocated resources and its expected profit in due time" (Malekinia 2005) In fact, to achieve the principle of return on resources. First of all, careful attention should be paid based on the required criteria and standards at the time of granting credit facilities. Because, more important than what is said about credit category: "granting credit is easy and credit retaining and collecting is difficult" is the fact that tolerance and negligence in granting credit facilities cause some problems in collecting them. Simply reliance on and attention to each of the criteria and standards is not enough in credit decision making, but a general attitude is required, which is capable to present a right and reliable basis to comment on a suggestion or to make a credit decision. In addition to recognizing criteria and standards, this attitude requires enough skill and knowledge and without them this important issue is not achievable necessarily. As bank resources mainly belong to depositors and bank as a depositary lawyer puts mentioned resources at customers' disposal in the constitutional credit system of interest-free banking, banks and credit brokers should try to use resources based on principles and reduce the possible credit risk (Ranjbar Motlagh 2005).

During their operations, all banks face risks which cannot be removed, but it is possible to manage them. Therefore, to continue their lives, banks should control and reduce risks. As it was said, banks face various forms of risks amongst them 4types, including credit risk, operational risk, market risk and liquidity risk do most damage to the banks' body.

As resources used for allocation are, in fact, financial institutions' debt to shareholders, people and banks that can weaken accreditation and debt repayment ability of financial institution if they do not flow, credit risk is of paramount importance in monetary and credit institutions. Especially that credit facilities and people deposits are considered as demands due at a future time and debts due at a future time in the balance sheet of monetary institution, respectively. It means that receivables collection in various times is impossible but payment of debts (deposits) is essential at each stage, otherwise monetary institution faces bankruptcy. Credit risk is one of the oldest and biggest risks that exist in transactions and credit risk, which arises due to borrowers failing to make required payments has been one of the biggest risks till now. It goes without saying that coping with credit risk accompanies with economic mechanisms and therefore, most banks use internal ranking system of improvements for borrowers. Credit risk arises of the uncertainty in the ability of a certain partner to achieve his goals. Increased diversity in the types of partners and a wide variety of tasks are some types of credit risk management, which have been transferred to the top of the risk-management activities (Shamsoldini 2010).

One of the most important risks banks exposed to be the credit risk or inability to pay risk. Equipping resources and allocating them in the form of facilities is the main duty of Iran's commercial banks. Considering that loan interest rate beyond monetary policies is used as a tool to apply economic policies in different economic sectors and banks granting facilities have been largely deprived from the possibility to compensate for the risk of nonrepayment of loans through fluctuations in interest rates, a comprehensive investigation of demand for facilities at the time of deciding on granting facility is of paramount importance to minimize the risk of non-repayment. Therefore, due to the very serious and potential effects of credit risk, it is very important to measure, control and manage it (Basle committee 1999).
Overdue claims and value date of banks and credit institutions of the country in recent years have exposed permanent increase. Of course, it is natural with regard to the growth of deposits volume and the amount of facilities granted by banks, but it should be considered that during recent years, banking network of the country has granted facilities by obtaining security, and a percentage of the mentioned facilities has always become overdue claims and value date of banks such that the ratio of overdue and value date claims of banks has taken a concerning trend in recent years (Honari Far 2011).

Concerning the importance of the issue on the one hand, and using risk credit indicators as one of main pillars of decision making during granting banking facilities on the other hand, the necessity to investigate and recognize credit risk in different banks of the country is felt more than before. Therefore, the current research is conducted to identify the relationship between accounting ratios as determining indicators of credit risk and the method of re-paying granted facilities to customers of Sepah Bank in East Azerbaijan and Ardabil provinces.

\section{Literature review}

In their research, Gholami and Salimi (2014) investigated the relationship between management of credit risk and liquidity management with profitability in the banking system. The results of research showed that variables such as liquidity management and credit risk management have a significant relationship with profitability variable in a banking system compared to other internal variables. Finally, considering the obtained results, some practical solutions have been suggested to increase profitability of the banks.

Shavalpour and Ashari (2013), investigated the effect of credit risk on the banks profitability in Iran. The results of the research showed that there is a significant negative relationship between credit risk and banks profitability. This relationship can be explained this way: by increasing credit risk, the cost of banks increases. Therefore, their profitability reduces. Considering the research results in it can be concluded that in order to increase profitability, managers of banking system should control the credit risk of the complex under their management.

In another study, Kimia Gari et al. (2012) investigated the model of credit risk for loan payback for credit customers of banks (Case study of Shahreza Branch of Melii Bank). Amongst different risks banks are exposed to, credit risk is of paramount of importance. For this reason, determining the credibility degree and the strength of the facilities receiver to repay the facilities granted and its interest is essential. The observed crises in the country's banking system have been mainly due to the inefficiency in credit risk management. In this research, using logistic regression, a sample of 31 companies, which received credit facilities from Melli Bank of Shahreza during 2007-2011 were investigated. To do this, 28 variables significant in banking system and in the view of experts in this field were selected and after separation of qualitative and quantitative ones, 15 main variables were selected, and data were analysed using SPSS software.

Khoshsima and Shahiki Tash (2011) investigated the effect of credit, operational, and liquidity risks on the efficiency of Iran banking system. Findings of the research indicated that there is a significant relationship between credit, operational, and liquidity risks and efficiency in Iran's banking system.

In a research titled "On the interrelation of liquidity and credit risk in banks", Imbierowiczi and Rauch (2014) investigated the mutual relation between liquidity risk and credit risk in all commercial banks of the united states during 1998-2010. In this research, some change indicators of credit and liquidity risk have been used in a variety of analyses to determine any type of relationship between these two risks. The obtained results showed that there is a positive but weak mutual relationship between credit risk and liquidity risk. The analysis of the inside bank liquidity and the outside bank credit risk confirms the strong and positive relationship between 
these two factors. Finally, it was found that both risk resources not only separately affect bank default probability but also influence it together.

\section{Research methodology}

This is a descriptive correlation research of multi-variable type, and historical data are used in this study. In order to review the literature, the library studies method was used. The statistical population of the research consists of credit-financial data, legal entities and companies that have used financial facilities of bank branches in the covered area of East Azerbaijan and Ardebil in a time period of 2012-2014.

According to the regulation of Central Bank and credit standards of Sepah Bank, customers who demand facilities more than 16 milliard rials are required to present audited financial statements. Considering this issue, credit-financial data of companies are divided into two groups as follows:

1) First group includes companies, which have presented audited financial statements to obtain facilities. This group consists of 80 observations.

2) The second group includes 290 companies, which have presented unaudited financial statements to obtain facilities.

Therefore, financial data of 370 companies have been gathered after referring to more than 60 Sepah Bank branches and extracting their credit data. In order to increase the accuracy of calculations, financial data of all available observations were used to test hypotheses after classifying into two categories: first categories are companies, which have presented audited financial statements at the time of demanding facilities ( 80 cases) and second category are those companies which have presented regular but unaudited financial statements (290 cases).

\section{Research hypotheses}

H1: There is a relationship between liquidity ratios and timely fulfillment of the customers' obligations in Sepah Bank.

$\mathrm{H} 2$ : There is a relationship between activity ratios and timely fulfillment of the customers' obligations in Sepah Bank.

H3: There is a relationship between leverage ratios and timely fulfillment of the customers' obligations in Sepah Bank.

$\mathrm{H} 4$ : There is a relationship between profitability ratios and timely fulfillment of the customers' obligations in Sepah Bank.

H5: There is a relationship between loan to collateral value ratio and timely fulfillment of the customers' obligations in Sepah Bank

\section{Research model and variables}

$y_{i}=\beta_{0}+\sum_{i=1}^{27} \beta_{i} x_{i}$

Where:

Dependent variable

$y_{i}$ : Timely fulfillment of the customers' obligations (dummy variable: if customers repay taken facilities in due time the value is one otherwise it is zero)

Independent variables:

Liquidity ratios

X1: Current ratio

Current ratio is obtained by dividing current assets by current liabilities. This ratio shows that how much current assets in rial a commercial unit has vs. one rial of current liability.

X2: Acid-test ratio

It is the more accurate test of company liquidity and is obtained by dividing quick assets (cash, short term investments and receivable accounts and documents) by current liabilities.

X3: Working capital: working capital is the current assets of an economic unit minus its current liabilities.
X4: current asset ratio: this ratio is obtained by dividing current assets of a company to its total assets.

Leverage Ratios

$\mathrm{X} 5$ : Fixed assets to equity ratio

X6: Debt to equity ratio

X7: Debt to asset ratio

$\mathrm{X} 8$ : Fixed assets to long-term debt ratio

$\mathrm{X} 9$ : Equity to assets ratio

$\mathrm{X} 10$ : Current debts to equity ratio

$\mathrm{X} 11$ : Long-term debt to equity ratio

X13: Current liabilities to working capital ratio

Activity Ratios (covering)

X14: Turnover frequency of receivable accounts: the ratio of receivable accounts turnover show the frequency collection of receivables (converting collection to cash) during the year and it is obtained by dividing net sales by average receivable accounts.

$\mathrm{X} 15$ : Inventory turnover: this ratio is obtained by dividing the cost of goods sold by the average inventory.

X16: Inventory to working capital ratio

X17: Working capital turnover ratio

X18: Fixed assets turnover ratio

X19: Total assets turnover ratio

Profitability Ratios

X20: Return on Sale (sales / net profit after tax)

X21: Return on total assets: this ratio is calculated by dividing net income after-tax deduction is made by average total assets.

$\mathrm{X} 22$ : Sale to total assets ratio

$\mathrm{X} 23$ : Return on equity: it is obtained by dividing net profit aftertax deduction is made by equity.

X24: Return on working capital: it is obtained by dividing net profit after-tax deduction is made by working capital.

$\mathrm{X} 25$ : Gross profit to sale ratio

X26: Operational costs to sale ratio

Collateral value to taken loan ratio

X27: Collateral value to loan ratio (the amount of taken loan/the amount of Collateral (bail))

\section{The research model estimation results}

Table 1 shows the estimation results of the research independent variables coefficients using logistic regression. This way, considering the significance level of each of the independent variables at $95 \%$ confidence level, the significance of the independent variables coefficient is determined.

As mentioned in the previous section, in order to measure the significance of coefficients of logistic regression function variables, Wald statistics is used. It should be explained that similar to investigation into the significance of linear regression function coefficients, here null hypothesis says that the intended variable has no relationship with dependent variable. As it can be seen from the above table the significance level of Wald statistics for coefficients of variables: current ratio, Acid-test ratio, working capital, return on sale, return on total assets and return on equity in unaudited financial statements group, is less than 0.05 . This means that the above null hypothesis is rejected for six mentioned variables. Therefore, these variables are significant at $95 \%$ confidence level. In addition, considering the estimated significance level in audited financial statements group, coefficients of variables current ratios, current assets, debt to equity, debt to asset, current liabilities to equity, turnover frequency of receivable accounts, total assets turnover are significant at probability level of $95 \%$ (table 1).

H1 testing: There is a relationship between liquidity ratios and timely fulfillment of the customers' obligations in Sepah Bank. In unaudited financial statements group: the results obtained by coefficients of independent variables and significance test of mentioned variables coefficients show that the current ratios $(-1.876)$, acid-test (1.062), and working capital (0.001), have a significant inverse, direct and direct relationship with dependent variable of the research, respectively. 
In audited financial statements: considering the estimated significance level, current ratio (32.020) and current asset (-63.009) have a significant direct and inverse relationship with dependent variable, respectively. In the light of the above it can be concluded that the first hypothesis is supported.

$\mathrm{H} 2$ testing: There is a relationship between activity ratios and timely fulfillment of the customers' obligations in Sepah Bank.

In unaudited financial statements group: considering the high level of significance probability (Sig) of activity ratio coefficients (at confidence level of 95\%), the lack of a significant relationship between activity ratios and timely fulfillment of the customers obligations in Sepah Bank is confirmed.

In audited financial statements group: turnover frequency of receivable accounts $(-0.0858)$ and total assets turnover $(6.002)$ by significance level of coefficients less than $5 \%$ have a significant relationship with dependent variable of the research indicating the second hypothesis confirmation.

H3 testing: There is a relationship between leverage ratios and timely fulfillment of the customers' obligations in Sepah Bank.

In unaudited financial statements group: the high level of significance probability (Sig) of coefficients of leverage ratios shows that there is no significant relationship between leverage ratios and timely fulfillment of the customers' obligations in Sepah Bank.

In audited financial statements group: considering the estimated level of significance probability for coefficients of this hypothesis variables, debt to equity ratios $(-5.838)$, debt to asset (49.890) and current liabilities to equity (6.961), have a significant relationship with independent variable indicating that the third hypothesis is confirmed.

$\mathrm{H} 4$ testing: There is a relationship between profitability ratios and timely fulfillment of the customers' obligations in Sepah Bank.

In unaudited financial statements group: considering the significance level of coefficients of independent variables, three ratios: return on sale ratio (-0.914), return on total assets (7.399), and return on equity (-5.378), have a significant relationship with timely fulfillment of the customers' obligations indicating that the fourth hypothesis is confirmed.

In unaudited financial statements group: none of the probability ratios have a significant relationship with timely fulfillment of the customers' obligations.

$\mathrm{H} 5$ testing: There is a relationship between loan to collateral value ratio and timely fulfillment of the customers' obligations in Sepah Bank.

In both groups of this research, the high level of significance (Sig) probability of collateral value to loan ratio coefficient (at the reliability level of $95 \%$ ), shows that there is no significant relationship between collateral value to loan ratio and timely fulfillment of the customers' obligations and the fifth hypothesis is rejected.

After estimating coefficients of independent variables of the model and investigating their significance level, here the entire logistic regression function significance and its goodness-of-fit are investigated.

In order to investigate the amount of goodness-of-fit of logistic regression function, Hosmer and Lemeshow, McFadden $\mathrm{R}^{\wedge} 2, \mathrm{R}^{\wedge} 2$ Snell and Cox and Nagelkerke statistics were used. The results obtained by testing mentioned statistics represented in table 2 indicate the significance of regression and goodness-of-fit of regression function.

Goodness-of-fit of regression function with coefficients mentioned in table 2 has been determined using Hosmer and Lemeshow, McFadden $\mathrm{R}^{\wedge} 2, \mathrm{R}^{\wedge} 2$ Snell and Cox and Nagelkerke statistics. Goodness-of-fit of logistic regression function of the group of customers who had presented audited financial statements is lower compared to the other group. Because, the significance level of Hosmer -Lemeshow statistics for the first and second group is 0.1 and 0.887 , respectively. The greater values of Hosmer Lemeshow statistics and values closer to one indicates that the function fits the observed data. Regarding the other three indicators the results of Hosmer-Lemeshow statistics are confirmed. According to table 3, the statistical population is the ratios extracted from unaudited financial statements including 290 companies.
Of these companies 208 cases have fulfilled their obligations in due time and 82 cases have been non-creditworthy and have not fulfilled their obligations in due time. The regression function obtained with regard to creditworthy customers (208 cases) has been able to predict correctly payment status of 200 cases and classified them in creditworthy customers group. And there are only 8 other cases which have not been classified correctly. The correct prediction of the function in creditworthy customers is $96.2 \%$. In addition, this function has been capable to correctly classify the payment status of 28 cases of non-creditworthy companies and classify the remained 54 cases incorrectly. The correct prediction of the function in non-creditworthy customers is $34.1 \%$ The correct prediction of the entire regression function in the audited group is $83.8 \%$ which is higher than the estimated amount for unaudited financial statements group $(78.6 \%)$.

\section{Optimized logistic regression function}

From 27 independent variables of the research, variables X9 (equity to assets ratio) and X22 (sale to total assets ratio) were not entered into the model at the first stage of regression analysis. In the extracted data from unaudited financial statements group, the coefficients of variables current, acid-test, working capital, gross profit to sale, return on total assets and return on equity ratios, and in the extracted data from audited financial statements group, the coefficients of variables current ratio, current asset, debt to equity, debt to asset, current liability to equity, turnover frequency of receivable accounts and total assets turnover ratio were significant. In order to obtain final logistic regression function, the significant variables of the first stage are entered again into the software. The estimated coefficients for variables at the second stage are presented in table 4.

At the second stage of regression analysis and in the extracted data from audited financial statements group, all independent variables were significant and the final function with correct classification power of $75 \%$ is as follows:

$$
\begin{aligned}
& \mathrm{y}_{\mathrm{i}}=-10.72+10.98 \mathrm{x}_{1}-17.26 \mathrm{x}_{4}-2.56 \mathrm{x}_{6}+14.62 \mathrm{x}_{7}+ \\
& 2.87 \mathrm{x}_{10}-0.26 \mathrm{x}_{14}+1.82 \mathrm{x}_{19}
\end{aligned}
$$

In the extracted data from unaudited financial statements group, at the third stage of regression analysis, three variables of current ratio, return on total assets and return on equity were significant. The final function with correct classification power of $73.1 \%$ is as follows:

$$
\mathrm{y}_{\mathrm{i}}=1.792-0.3325 \mathrm{x}_{1}+8.0155 \mathrm{x}_{21}-5.1658 \mathrm{x}_{23}
$$

\section{Conclusion and suggestions}

1-Of 4 liquidity ratios extracted from unaudited financial statements, current, acid-test and working capital ratios, and amongst ratios extracted from audited financial statements, current ratio and current asset ratio at the confidence level of $5 \%$ have a significant relationship with timely fulfillment of the customers' obligations. It is worth mentioning that the estimated significance level (Sig) for liquidity ratios of audited financial statements group is less than that of unaudited financial statements group. This difference is more perceptible in the ratios which have a significant relationship with dependent variable. A large number of members of the statistical population of the research have used short-term and medium-term credit facilities. We know that liquidity ratios show a commercial unit ability to fulfill short-term obligations. Considering that most of the liquidity ratios have a significant relationship with timely repaying of credit facilities, the results of the first hypothesis are almost in compliance with accounting knowledge.

2-At the significance level of 5\%, none of the estimated ratios of activity for customers who have presented unaudited financial 
statements have a significant relationship with customers' timely fulfillment of obligations. Of the activity ratios extracted from audited financial statements, the turnover frequency of receivable accounts and total assets turnover ratio have a significant relationship with customers' timely fulfillment of obligations. In banking industry, the activity ratios are considered to be very strong tools to analyse the status of customers' facilities. The results of testing this hypothesis in data extracted from audited financial statements group are in agreement with theoretical and practical principles of customers' assessment in bank. In data extracted from unaudited financial statements group, the conditions are in contrast with the previous mode.

3-Of leverage ratios, in audited financial statements group, debt to equity ratio, and debt to asset ratio and current liabilities to equity ratio have a significant relationship with timely fulfillment of customers' obligations. In unaudited group, none of the leverage ratios have a significant relationship with dependent variable of the research. Most of the companies in the sample (especially noncreditworthy customers group) have used cooperative facilities of bank from small and medium sized enterprises. The participation amount of plan executors in partnership contracts has been often low and about $25 \%$. This fact was seen more in companies which have not presented audited financial statements. Therefore, a greater percentage of the left side of balance sheet of these companies is composed of banking facilities. It is obvious that such a financial structure affects companies' obligations fulfillment, and along with it should see a strong relationship between leverage ratios and fulfilling obligations in these companies. In the group of data extracted from audited financial statements, findings by testing this hypothesis are partly in agreement with scientific facts, but in the other group the opposite is true.

4-There was a significant relationship between timely fulfillment of customers' obligations and profitability ratios, return on total assets ratios, return on equity and gross profit to sale ratio in the group of customers who have presented unaudited financial statements. None of the profitability ratios extracted from audited financial statements has a significant relationship with dependent variable of the research. Returning the origin and the profit of the allocated resources in long-term depends greatly to profitability of a commercial unit. Considering the small sample size of the companies which presented audited financial statements (80 cases) on the one hand, and on the other hand regarding that granted facilities to customers in audited group is often working capital or of medium-term type, the ability to repay these facilities is usually assessed by analyzing liquidity ratios, in practice no significant relationship should have been seen between profitability ratios and fulfilling obligations by customers. The results of fourth hypothesis testing in this group confirm these statements as well. In the group of data extracted from unaudited financial statements the opposite is true.

5-The collateral value to loan ratio in both groups has no significant relationship with fulfilling customers' obligations. Different types of collateral (bail) banks receive to cover granted facilities in terms of credibility and liquidity rate are various types of deposits, stock of holding company, bonds, movable property and fixed assets and valuable and realizable assets, and persons' guarantees, and etc.

Except authentication of different deposits (which are rarely accepted by customer due to the importance of cash), achieving to bank interests using other types of bails is usually time consuming and leads to special difficulties. Usually banks use this method as the last solution.

Therefore, the results obtained by testing this hypothesis are consistent with banking operation realities. In sum, the results of testing the research hypotheses using logistic regression method can be expressed as follows:
- Accounting, current, acid-test and working capital, return on total assets, return on equity and gross profit to sale ratios in unaudited financial statements and current ratio, current assets ratio, turnover frequency of receivable accounts, total assets turnover, debt to equity, debt to asset and current liabilities to equity ratio in audited financial statements group have a significant relationship with timely fulfillment of customers obligations

- The relationship between accounting ratios and timely repaying of facilities both in terms of number and intensity is more significant in audited financial statements group. In addition, the goodness of fit of regression function or the correct prediction power of this function in audited group is $83.8 \%$ and higher than the estimated amount for unaudited financial statements group $(78.6 \%)$.

The correct prediction of regression function in noncreditworthy customers group is very low, because regression function classifies customers based on their information and characteristics and due to the lower interest rate and banking late penalty than the return rate in other financial markets, non-creditworthy customers are not willing to fulfill their obligation in due time though they have a high financial power and favorable financial ratios.

- As access to relevant and timely financial data plays a fundamental role in investigating customers' credit risk, creating efficient databases for customers is considered as the basic tool for research and decision makings. Meanwhile, it seems necessary to connect internal databases to databases of institutions such as Companies Registration Office, Deeds and Real Estate Registration Department, Economy and Finance Affairs Organization, Central Bank, Stock Exchange, and etc., to update customers' information constantly through the acquisition of the necessary licenses and proposing the issue in the commission of coordinating council of banks.

- Considering the importance of risk category, it is recommended to establish research sector and research on risk sector at general level and research councils in each of the regions and provinces management, to equip them and develop their activity to achieve new and efficient scientific models and to monitor, control and reduce different types of risks

- Though this research could present significant linear functions between financial ratios and timely fulfillment of customers' obligations, its results cannot be generalized to and used in the entire country. For further research it is suggested to conduct similar research at all banks level.

- Valuing accounting and auditing process and requiring facilities customers to present regular and audited financial statements at each level of demand (in terms of facilities amount) by monetary and credit policymaking institutes and on the top of them Central Bank increase the disclosure level and improve informational environment on the one hand, and on the other hand create a secure and reliable environment for those grant credit and facilities to decide.

- It is essential to establish professional institutions with a high degree of independence and professional skills to grade and rank credit customers, because using the determined ranks by them not only help with decision making of those who grant credit, but also avoid potential conflict between customer and those grant credit. In this regard, outsourcing credit rating and customers validation process, facilitates the decision making issue for credit-financial institutions and banks to investigate demands. 
Table 1: The Estimated Coefficients of Independent Variables

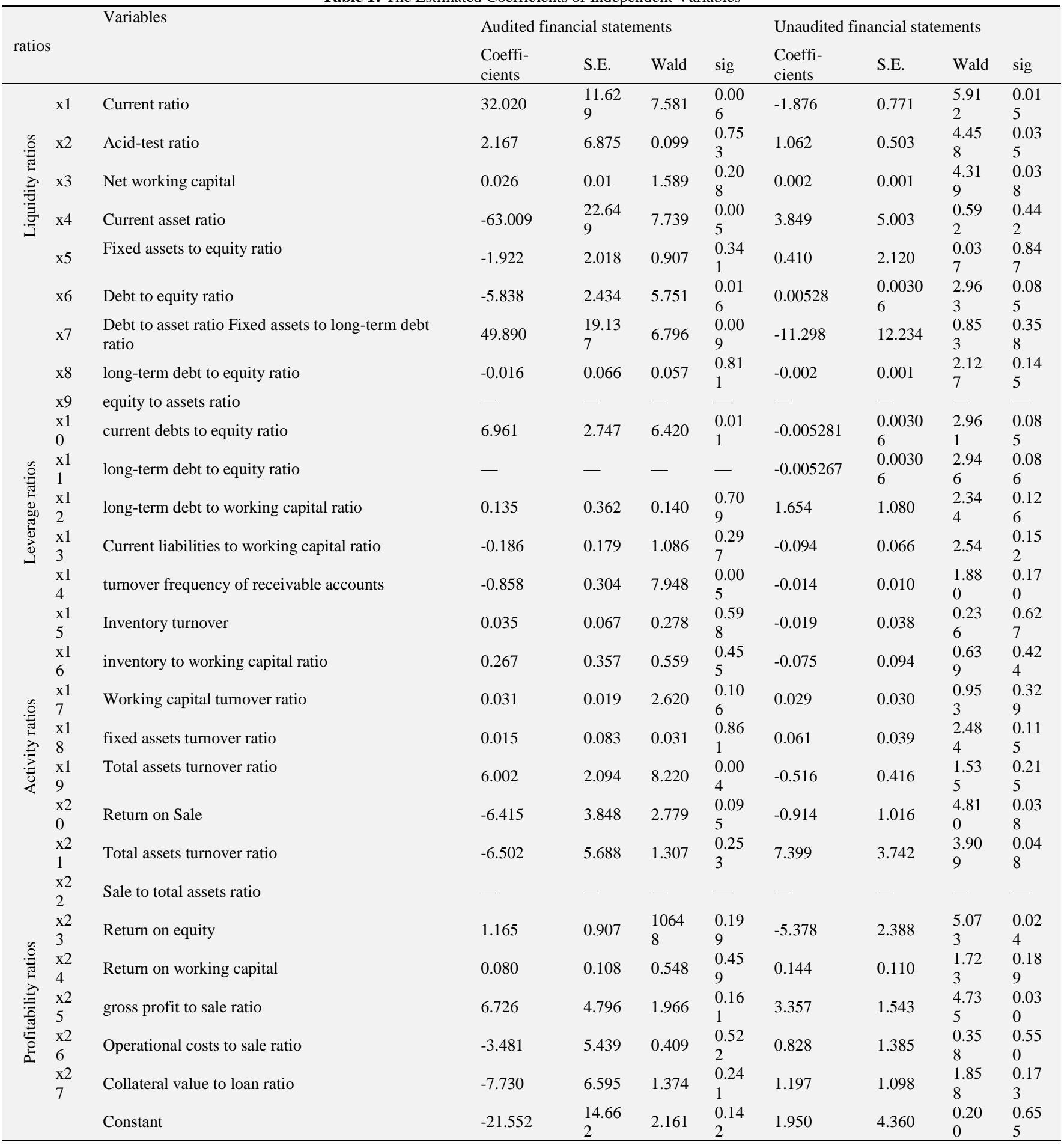

Table 2: Model Summary

\begin{tabular}{|c|c|c|c|}
\hline Group & Hosmer and Lemeshow Test & Chi-square & sig \\
\hline \multirow{4}{*}{ Unaudited financial statements } & & 13.377 & 0.100 \\
\hline & )McFadden( & 0.175 & - \\
\hline & Cox \& Snell R Square & 0.188 & - \\
\hline & Nagelkerke R Square & 0.270 & - \\
\hline \multirow{3}{*}{ Audited financial statements } & Hosmer and Lemeshow Test & Chi-square & sig \\
\hline & )McFadden( & 1.000 & - \\
\hline & Cox \& Snell R Square & 0.717 & - \\
\hline
\end{tabular}


Table 3: Classification Table

\begin{tabular}{|c|c|c|c|c|}
\hline \multirow{5}{*}{ 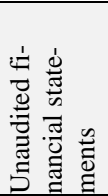 } & \multirow[b]{2}{*}{ Observed } & \multicolumn{3}{|l|}{ Predicted } \\
\hline & & \multirow{4}{*}{$\begin{array}{l}\text { y } \\
\text { Non-creditworthy } \\
28 \\
8 \\
78.6 \% \\
\end{array}$} & \multirow{4}{*}{$\begin{array}{l}\text { Creditworthy } \\
54 \\
200\end{array}$} & \multirow{4}{*}{$\begin{array}{l}\text { Percentage Correct } \\
34.1 \% \\
96.2 \%\end{array}$} \\
\hline & Non-creditworthy & & & \\
\hline & Creditworthy & & & \\
\hline & & & & \\
\hline \multirow{3}{*}{ 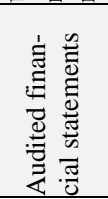 } & \multirow[b]{2}{*}{ Observed } & \multicolumn{3}{|l|}{ predicted } \\
\hline & & y & & Percentage Correct \\
\hline & Creditworthy & $\begin{array}{l}5 \\
83.8 \%\end{array}$ & 49 & $90.7 \%$ \\
\hline
\end{tabular}

Table 4: Estimated Coefficients for Independent Variables in the Final Function

\begin{tabular}{|c|c|c|c|c|c|}
\hline $\begin{array}{l}\text { Unaudited financial statements } \\
\text { variable }\end{array}$ & & Coefficients & S.E. & Wald & Sig \\
\hline Current ratio & $\mathrm{x} 1$ & 10.982 & 4.490 & 5.982 & 0.014 \\
\hline Current asset ratio & $\mathrm{x} 4$ & -17.263 & 6.572 & 6.890 & 0.009 \\
\hline Debt to asset ratio & $\mathrm{x} 7$ & 14.639 & 5.899 & 6.159 & 0.013 \\
\hline Current liabilities to equity ratio & $\mathrm{x} 10$ & 2.871 & 1.125 & 6.514 & 0.011 \\
\hline turnover frequency of receivable accounts & $\mathrm{x} 14$ & -0.262 & 0.128 & 4.185 & 0.041 \\
\hline Total assets turnover ratio & $\mathrm{x} 19$ & 1.827 & 0.867 & 4.442 & 0.035 \\
\hline \multicolumn{6}{|l|}{ Constant } \\
\hline \multicolumn{6}{|l|}{ Audited financial statements } \\
\hline Current ratio & $\mathrm{x} 1$ & -0.3325 & 0.1346 & 6.1 & 0.013 \\
\hline Return on total assets & $\mathrm{x} 21$ & 8.0155 & 2.8883 & 7.7 & 0.005 \\
\hline Return on equity & $x 23$ & -5.1658 & 1.5471 & 11.15 & 0.0008 \\
\hline Constant & & 1.792711 & 0.2978 & 360226 & 0.000 \\
\hline
\end{tabular}

\section{References}

[1] Erfani, A R, Hemati, M, (2014), ranking the factors affecting banking sources TOPSIS method in Semnan province (TOPSIS), Semiannual journals of Monetary, Financial Economics, 21st year, No 8.

[2] Bahmand, M and Bahmani, M, (2007), Domestic banking (equipping monitory resources), Higher Institute of Banking publication, Iran, Tehran

[3] Malekinia N, (2005), designs loan optimal portfolio to reduce credit risk level, Master Thesis, Shahid Beheshti University, Iran.

[4] Ranjbar Motlagh, L, (2005), Principles of credit risk management, Department of Banking Studies and Regulations, Central Bank of the Islamic Republic of Iran.

[5] Shamsoldini, A, (2010), Principle of Bank Saderat credit risk management. 10th year.

[6] Honari Far, M, (2011), investigating the relationship between credit risk and unpaid receivables of banks, Master Thesis, Islamic Azad University, Central Tehran Unit.

[7] Gholmi, A and Salimi, Y (2014), Investigation of the relationship between management of credit risk and liquidity management with profitability in the banking system, first International Conference on Economics, Management, Accounting and Social Sciences, Rasht.

[8] Shavalpour, S, Ashari, E (2013). Investigating the effect of credit risk on the banks profitability in Iran. Financial research, 15, 2.

[9] Kimia Gari, M A, Amini, M J, Tabatabaei Arani, H, Hosseini, (2012), Model of credit risk for loan payback for credit customers of banks (Case study. Shahreza Branch Bank Meli), 9th International Conference of Industrial Engineering, Tehran, Iran Institute of Industrial Engineering, University of Khajeh Nasir al-Din alTusi, http://www.civilica.com/Paper-IIEC09-IIEC09_203.html

[10] Khosh-sima, R, Shahiki-Tash M N, (2011). The effect of credit, operational and liquidity risks on the efficiency of banking system in Iran. The Journal of Planning and Budget, 17th year, No4.

[11] Imbierowiczi, B, Rauch, C, (2014), «On the Interrelation of Liquidity and Credit Risk in Banks», Journal of Banking \& Finance 40 (2014) 242-256. https://doi.org/10.1016/j.jbankfin.2013.11.030.

[12] Basle committee of Banking supervision, (1999) Credit Risk Modeling: current practices \& Applications1999. 